\title{
Wstęp do metodologii oceny dotykowych modeli architektonicznych
}

\section{Maciej Kłopotowski}

Politechnika Białostocka, Wydział Budownictwa i Inżynierii Środowiska, Katedra Konstrukcji Budowlanych i Architektury.

Zrealizowano w ramach pracy statutowej SMBilŚ/2/16 finansowanej ze środków MSWiN

\section{Agnieszka Kłopotowska}

Politechnika Białostocka, Wydział Architektury, Katedra Architektury Mieszkaniowej, Pracownia Urbanistyki i Planowania Przestrzennego

Zrealizowano w ramach pracy statutowej S/WA/1/17 finansowanej ze środków MSWiN

\begin{abstract}
Streszczenie: W niniejszej publikacji podjęto tematykę dotykowych modeli architektonicznych, instalowanych w przestrzeniach publicznych polskich miast. Zamieszczono w niej wyniki badań autorskich, których celem było wskazanie cech i działań determinujących jakość tego rodzaju opracowań, w tym ich użyteczność dla osób niewidzących. Na podstawie analizy rzeczywistych realizacji zdefiniowane zostały cechy, które usystematyzowano w odpowiednich obszarach i aspektach problemowych. Dla każdego z nich podano rozwiązania pożądane, dopuszczalne od nich wyjątki, a także rozwiązania niedopuszczalne. Wskazano również podmioty odpowiedzialne za poszczególne elementy w procesie projektowania, realizacji oraz użytkowania tego rodzaju reprezentacji. Autorska metoda może stanowić podstawę do dalszych prac badawczych, poświęconych opracowaniu i wykorzystaniu metodologii oceny dotykowych modeli architektonicznych.
\end{abstract}

Słowa kluczowe: przestrzeń publiczna, projektowanie uniwersalne, modele dotykowe, rzeźba architektoniczna, pomoce tyflologiczne

\section{Wprowadzenie}

Od ponad dziesięciu lat w przestrzeniach zewnętrznych polskich miastach instalowane są modele i makiety, które przeznaczone są do oglądu dotykowego. Do dnia dzisiejszego zrealizowano ich kilkadziesiąt. Wśród nich znajdują się odwzorowania przestrzeni krajobrazowej, architektonicznej a także portrety ${ }^{1}$ oraz przedstawie-

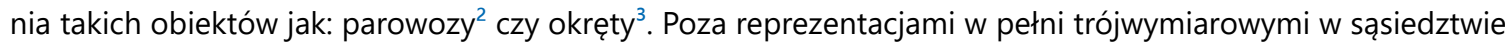
wielu obiektów architektonicznych oraz w ich wnętrzach realizowane są odwzorowania reliefowe. Wszystkie one stanowią interesujące elementy wyposażenia przestrzeni publicznej a zarazem elementy promocji miast. Jako element uniwersalny spełniają one ważną rolę społeczną. Służą celom dydaktycznym i poznawczym osób o różnych możliwościach i potrzebach percepcyjno-ruchowych. Możliwość dotykania ekspozycji czyni z nich narzędzie tyflodydaktyczne i zastępczą formę poznania dla osób niewidomych i słabowidzących.

Autorzy niniejszego opracowania przeprowadzili pionierskie w naszym kraju badania obejmujące swym obszarem modele ilustrujące przestrzenie i obiekty architektoniczne. Prace przeprowadzono w 31 miastach i miasteczkach Polski. W trakcie ich prowadzenia dokonano szczegółowych pomiarów i dokumentacji

1 Między innymi popiersie Jana Matejki, zrealizowane w Krakowie przy ul. Floriańskiej w ramach trasy Droga Królewska dla Niepełnosprawnego Turysty.

2 Trzy modele dotykowe historycznych parowozów eksponowane są w Muzeum Kolejnictwa w Kościerzynie.

3 Model ORP Błyskawica eksponowany jest na Nabrzeżu Kościuszkowskim w Gdyni. 
fotograficzno-rysunkowej. Analizami objęto łącznie 74 obiekty. Terenowe prace badawcze poszerzone zostały o kwerendy odbyte w stosownych instytucjach i urzędach oraz wywiady przeprowadzone ze zleceniodawcami, autorami i wykonawcami badanych modeli.

Wyniki przeprowadzonych studiów jednoznacznie wskazują na istnienie szeregu niedociągnięć i mankamentów projektowo-wykonawczych, które obniżają lub wręcz wykluczają przydatność poszczególnych realizacji Przyczyn tego autorzy upatrują w braku właściwych i odpowiednio spopularyzowanych zasad projektowania, uzgadniania, opiniowania, realizacji oraz eksploatacji tego rodzaju mebli miejskich. Nie bez znaczenia pozostają również takie fakty jak: brak odpowiedniej wiedzy i doświadczenia projektantów ${ }^{5}$ w zakresie projektowania uniwersalnego, incydentalny i eksperymentalny charakter modeli ( $w$ wielu miastach realizowanych jako pojedyncze obiekty) ${ }^{6}$, oraz ograniczające przesłanki ekonomiczne ${ }^{7}$.

Wprowadzona przez autorów metodologia analizy poszczególnych realizacji pozwoliła na wskazanie obszarów problemowych. Stanowią je: problemy związane z lokalizacją w przestrzeni, budową postumentu pod model, rzeźbą modelu - jego treścią merytoryczną, zawartą na modelu informacją oraz problemy związane z budową i eksploatacją modelu. Uszczegółowienie tych obszarów w formie kolejno: aspektów i dalej konkretnych elementów, pozwala na prześledzenie najczęściej popełnianych błędów. Na tej podstawie autorzy dokonali oceny istniejących realizacji. Wyniki tego procesu pozwoliły również na swoisty eksperyment naukowy, polegający na wskazaniu cech i rozwiązań mogących stać się przyczynkiem do opracowania wytycznych projektowych i realizacji opracowań wzorcowych. Działania te w przyszłości mogą doprowadzić również do budowy narzędzia umożliwiającego ocenę tego rodzaju opracowań.

\section{Analizowane obszary, aspekty i elementy problemowe}

W zamieszczonej poniżej tabeli przedstawiono usystematyzowany zestaw cech i działań: pożądanych (wzorcowych), dopuszczalnych (akceptowalnych pod pewnymi warunkami) oraz niedopuszczalnych (całkowicie wykluczonych). Usystematyzowano je w grupach problemowych, które określono jako: obszary, aspekty i elementy. Pod pojęciem obszarów sklasyfikowano podział na: lokalizację, postument, treść, informację oraz budowę i eksploatację. Podział ten ma przełożenie na proces inwestycyjny, kolejność wykonywanych prac i czynności oraz podmioty za nie odpowiedzialne.

Obszar lokalizacji wiąże się z decyzjami lokalizacyjnymi, które należą do inwestora a jednocześnie władz publicznych. Sklasyfikowano w nim takie aspekty jak: miejsce oraz trasa dojścia do modelu. Elementy te związane są z wyborem odpowiedniej lokalizacji, spełniającej wymogi łatwego odnalezienia w przestrzeni, widoczności z ciągów komunikacyjnych oraz orientacji odwzorowania względem oryginalnego obiektu/obiektów w przestrzeni realnej miasta. Drugim z aspektów są decyzje związane z parametrami przestrzennymi i organizacją bezpiecznej trasy dojścia do modelu z głównych ciągów komunikacji pieszej. Decyzje takie najczęściej pozostają w gestii

4 Problemy te autorzy prezentowali podczas następujących konferencji naukowych i branżowych:

- Konferencji naukowej pt.: Nowocześni niewidomi i słabowidzacy w dostosowanym do nich świecie, Serock $28-29$ października 2016 r.;

- IV/VII Międzynarodowa konferencja z cyklu Architektura bez granic, pt.: Miasto - stolica kultury. Wyzwania i efekty, Wrocław 18-19 listopada 2016 r.;

- III Ogólnopolskiej Konferencji Naukowo-Szkoleniowej Medycyna personalizowana. „Genom-Człowiek-Świat-Zagrożenia”, Lublin 23-25 listopada 2016 r.;

- XIV edycja Międzynarodowej Konferencji Reha for the Blind. Świat Dotyku, Dźwięku i Magnigrafiki - „Wybitni niewidomi - ich wptyw na rozwój nowoczesnych społeczeństw", Warszawa 01-02 grudnia 2016 r.;

- Konferencji pt.: Nowoczesne społeczeństwa i władze Unii Europejskiej, a także polskie i województwa świętokrzyskiego rozwiązują problemy niewidomych i stabowidzących, Kielce 02 marca 2017 r.;

- World Multidisciplinary Civil Engineering-Architecture-Urban Planning Symposium, Praga $12-16$ czerwca 2017 r.;

- XX Forum Architektury Krajobrazu, pt.: Praktyka zawodowa - Badania naukowe - Dydaktyka, Kraków 21-23 września 2017 r.

- XV edycja Międzynarodowej Konferencji Reha for the Blind. Świat Dotyku, Dźwięku i Magnigrafiki, Warszawa 17-18 października 2017 r.;

5 W procesach realizacji analizowanych 74 obiektów uczestniczyło niemalże 30 twórców. Są wśród nich autorzy pojedynczych realizacji, co ma miejsce w 16 przypadkach. Zaledwie 4 twórców zrealizowało łącznie powyżej 5 takich modeli.

6 W 20 miastach zrealizowano po jednym modelu. Fakt ten nie pozwala na wzajemne porównywanie opracowań i wyciąganie odpowiednich wniosków z innych realizacji (uczenie się na błędach). Wyłącznie w 9 ośrodkach zobaczyć można więcej niż dwie różne reprezentacje. Więcej przykładów oferują odpowiednio: Kraków (13 opracowań), Wrocław (8), Gdańsk (6), Sandomierz (5), Poznań (4), Kościerzyna (3), Karpacz (2). W trzech miastach (w Pasłęku, Świdnicy i Warszawie) udostępniono natomiast zwielokrotnione kopie tego samego odwzorowania.

7 Realizacje te bywają częścią procesów inwestycyjnych polegających na dostosowaniu obiektów i przestrzeni do potrzeb osób niepełnosprawnych które realizowane są w wyniku tak zwanych przetargów. O wyborze wykonawcy w sytuacjach takich decyduje cena. W wielu wypadach generuje to problemy jakościowe. 
zarządcy budynku lub dysponenta przestrzeni publicznej a realizacja obiektów we wskazanych miejscach może wiązać się z przebudową fragmentu przestrzeni publicznej (najczęściej zmiany te obejmują: przebudowę nawierzchni, rearanżację elementów małej architektury oraz oświetlenie). W obszarze lokalizacji wyszczególniono również aspekt otoczenia modelu. Miejsce to, podobnie jak opisane powyżej, wymagać może przebudowy lub przearanżowania przestrzeni, w której ustawiony zostanie model. Działania takie wymagają ścisłej współpracy pomiędzy autorem modelu i dysponentem konkretnej przestrzeni. Istotnym aspektem związanym z obszarem lokalizacji pozostają pozawzrokowe systemy naprowadzające, pozwalające odnaleźć model osobom z dysfunkcjami wzroku. W autorskim zestawieniu cech i rozwiązań podzielono je na klasyczne oznaczenia fakturalne oraz nowatorskie systemy elektroniczne (takie jak: GPS, bluetooth, beacon).

Obszar postumentu wiąże się bezpośrednio z ekspozycją rzeźby modelu. W odróżnieniu od obszaru lokalizacji zasadniczy wpływ na jego ostateczny kształt i wygląd mają: autor modelu oraz wykonawca. W obszarze tym rozpatrywano zagadnienia związane z ergonomią odbiorcy oglądającego model oraz uwarunkowaniami budowlanymi i estetycznymi. W aspekcie blatu ekspozycyjnego analizowano jego kształt oraz parametry poziome i pionowe. Element nośny (noga z blatem lub jednolity cokół) analizowany był również w kontekście podcięcia umożliwiającego dostęp do blatu ekspozycyjnego istotny szczególnie dla osób poruszających się na wózku inwalidzkim. W aspekcie tym zwrócono uwagę na takie elementy jak: stabilność optyczna konstrukcji (takie osadzenie rzeźby modelu na postumencie, które daje wrażenie równowagi optycznej) oraz estetykę postumentu ( $w$ tym harmonii estetycznej z elementami otoczenia oraz modelem). Problem ten wydaje się szczególnie istotny z uwagi na fakt, iż wykonawcą postumentu nie musi być autor modelu.

W obszarze treści wyróżniono szereg aspektów plastycznych, dydaktycznych i poznawczych będących w gestii artysty rzeźbiarza (autora reprezentacji modelarskiej) oraz ewentualnych konsultantów (reprezentujących grono specjalistów w zakresie tyflografiki, w tym osób niewidomych). Analizie poddano aspekt ekspozycji treści, w którym mieszczą się takie elementy jak: odpowiedni profil płyty stanowiącej ekspozytor modelu oraz właściwe rozmieszczenie na nim treści poznawczych. Drugim z aspektów jest treść zasadnicza, rozumiana jako główne odwzorowanie modelarskie. Wpływ na efekt ostateczny rozwiązań mają tu takie elementy jak: odpowiednio określone granice obszaru opracowania, fizyczna wielkość (parametry poziome i pionowe) rzeźby, właściwie dobrana skala odwzorowania, odpowiednia generalizacja obrazu (stopień jego nasycenia detalem), właściwa konwencja przedstawienia oraz zastosowane na modelu zasadniczym faktury i symbole. Kolejnym z aspektów jest treść uzupełniająca, którą tworzą towarzyszące obrazowi zasadniczemu uzupełnienia takie jak: miniatura, odpowiednie pomniejszenia i powiększenia przestrzenne (ewentualne przedstawienia detalu oraz kontestu). Istotnym aspektem są również oznaczenia towarzyszące treści, wśród których należy odnotować obowiązkowy opis skali, oraz pożądane w danych typach odwzorowań: oznaczenie "Tu jesteś", legendę oraz oznaczenie kierunków geograficznych. Oznaczenia te analizowano również w ujęciu alternatywnym - związanym z percepcją dotykową.

Szczególnie newralgicznym obszarem problemowym jest obszar informacji. Rozwiązania wykonywane przez artystę rzeźbiarza w zakresie tym muszą być niezbędnie poddawane wielostopniowym konsultacjom z gronem eksperckim z zakresu tyflologii, w tym obowiązkowo weryfikowane przez osoby niewidzące. W obszarze tym analizom poddano takie elementy jak: stałe (możliwie niezmienne na wszystkich modelach) rozmieszczenie elementów informacji oraz ich kompozycja, zgrupowane w aspekcie ekspozycji informacji. Ponadto w obszarze tym podniesiono problematykę identyfikatorów modelu. W aspekcie tym mieszczą się elementy uznane za niezwykle pożądane, takie jak: godło modelu oraz sprecyzowany tytuł opracowania. Ważnymi elementami są również: strona redakcyjna komunikatów słownych, wersje językowe oraz sposób rozmieszczenia, analizowane w aspekcie opisów. Podobnie jak ma to miejsce w odniesieniu do treści merytorycznej, w obszarze informacji analizowano aspekty alternatywnych sposobów przekazywania informacji. Na plan pierwszy wysuwa się kwestia odpowiedniego ubrajlowienia informacji. Rozwiązaniem pomocniczym może stać się natomiast udźwiękowienie opisów.

Ostatnim z wyróżnionych obszarów jest obszar technologia i eksploatacja modeli. Zgrupowano w nim zagadnienia z zakresu budowy i utrzymania obiektu. Podmiotami odpowiedzialnymi za tę grupę problemów stają się więc autor i wykonawca (w zakresie budowlanym i plastycznym) oraz zarządca przestrzeni, w której usytuowany jest model. Aspekt bezpieczeństwa i trwałości modelu wiąże się z takimi elementami jak: bezpieczeństwo konstrukcji nośnej - związane z potrzebą utrzymania modelu z uwzględnieniem czynników zagrożenia aktami wandalizmu, oraz bezpieczeństwo odbiorcy (zwłaszcza osoby niewidzącej) - związane z procesem 
percepcyjnym wszystkich partii opracowania. W grupie tej sklasyfikowano również aspekt instalacji dodatkowych takich jak odwodnienie (niezbędne w modelach zawierających niecki) oraz ewentualne podgrzewanie płyty i rzeźby modelu. Zadania zarządcy przestrzeni zgrupowane zostały w aspekcie zasad użytkowania, obejmujących elementy konserwacji ( $w$ tym kontroli bezpieczeństwa konstrukcji, doraźnych napraw) oraz oczyszczania.

\section{Charaktrystyka cech i działań}

Wyłonionym i zaprezentowanym powyżej elementom przyporządkowano cechy i działania określające rozwiązania: pożądane, dopuszczalne oraz niedopuszczalne.

Cechy i działania pożądane - zawarto w nich opis rozwiązań przestrzennych, ergonomicznych, modelarskich, tyflologicznych, artystycznych, technologiczno-materiałowych oraz użytkowych, uznanych za dobre wzorce. Wyłoniono je w drodze analizy szczegółowej już istniejących rozwiązań. Włączono w nie również cechy i działania, które dotychczas nie zostały wystarczająco spopularyzowane lub też nie zostały dotychczas wdrożone, a które to, w przekonaniu autorów, byłyby korzystne w dalszym rozwoju omawianej gałęzi modelarstwa. Rozwiązania te powinny stać się ewidentnym wzorcem wyznaczającym standardy przyszłych realizacji.

Cechy i działania dopuszczalne - dla wybranych cech i działań opracowano rozwiązania dopuszczalne, akceptowalne w pewnych szczególnych warunkach, kiedy niemożliwe jest wprowadzenie rozwiązań w pełni pożądanych. Odstępstwa takie odnoszą się do dostępności fizycznej do postumentu lub też treści modelu. Ograniczenia te mogą być następstwem specyficznych uwarunkowań lokalizacyjnych. Każdorazowo powinny być one kompensowane zastosowaniem dodatkowych udogodnień.

Cechy i działania niedopuszczalne - zdefiniowano zestaw cech i działań negatywnych, które autorzy sklasyfikowali jako: niebezpieczne, niewygodne, niekorzystne, nieprzydatne dla odbiorcy. Jak wynika z analiz autorskich, tego rodzaju mankamenty i błędy, obniżające wartość modeli i makiet jako uniwersalnych mebli miejskich, mogą pojawić się podczas: projektowania, realizacji lub też użytkowania modelu. Rozwiązania takie zdaniem autorów należy całkowicie wykluczyć ze względu na ich szkodliwość, rozumianą w ujęciu jednostkowym (konkretnej realizacji) ale również w kontekście ich wpływu na potencjalne kształtowanie i utrwalanie złych wzorców w kolejnych realizacjach.

Opracowanie uzupełniono uwagami, w których wymieniono osoby bądź organy odpowiedzialne za konkretny cechy i działania oraz podano informacje uzupełniające.

\section{Podsumowanie}

Opracowany przez autorów i zaprezentowany powyżej zestaw cech i działań stanowi nowatorskie narzędzie umożliwiające:

- precyzyjne określenie zadań związanych z projektowaniem, realizacją i użytkowaniem dotykowych modeli architektonicznych, instalowanych w przestrzeniach publicznych,

- określenie zakresu odpowiedzialności poszczególnych uczestników procesu inwestycyjnego dla tego rodzaju realizacji,

- wskazanie pożądanej jakości rozwiązań: projektowych, realizacyjnych i użytkowych, gwarantujących jakość i bezpieczeństwo omawianych opracowań,

- wskazanie rozwiązań niedopuszczalnych celem zapobieżenia ich realizacji i udostępnienia publicznego.

Autorzy widzą potrzebę kontynuowania rozpoczętej pracy w kierunku precyzyjnego określenia i wdrożenia w życie jednolitych dla całego kraju wytycznych projektowo-realizacyjnych (tak zwanych standardów). Opracowanie takiego dokumentu pozwoli w przyszłości na uniknięcie spotykanych dziś niedociągnięć i wad. Jednocześnie uprawni do kontrolowania jakości kolejnych realizacji. Weryfikacja taka powinna być możliwa na wszystkich etapach procesu inwestycyjnego a jej uczestnikami powinny być odpowiednie służby i organa publiczne oraz eksperci tematu i potencjalni użytkownicy. Zdaniem autorów wdrożenie takich wytycznych przyczyni się również do analizy realizacji już istniejących a być może zaowocuje także ich dostosowaniem do obowiązujących standardów. 

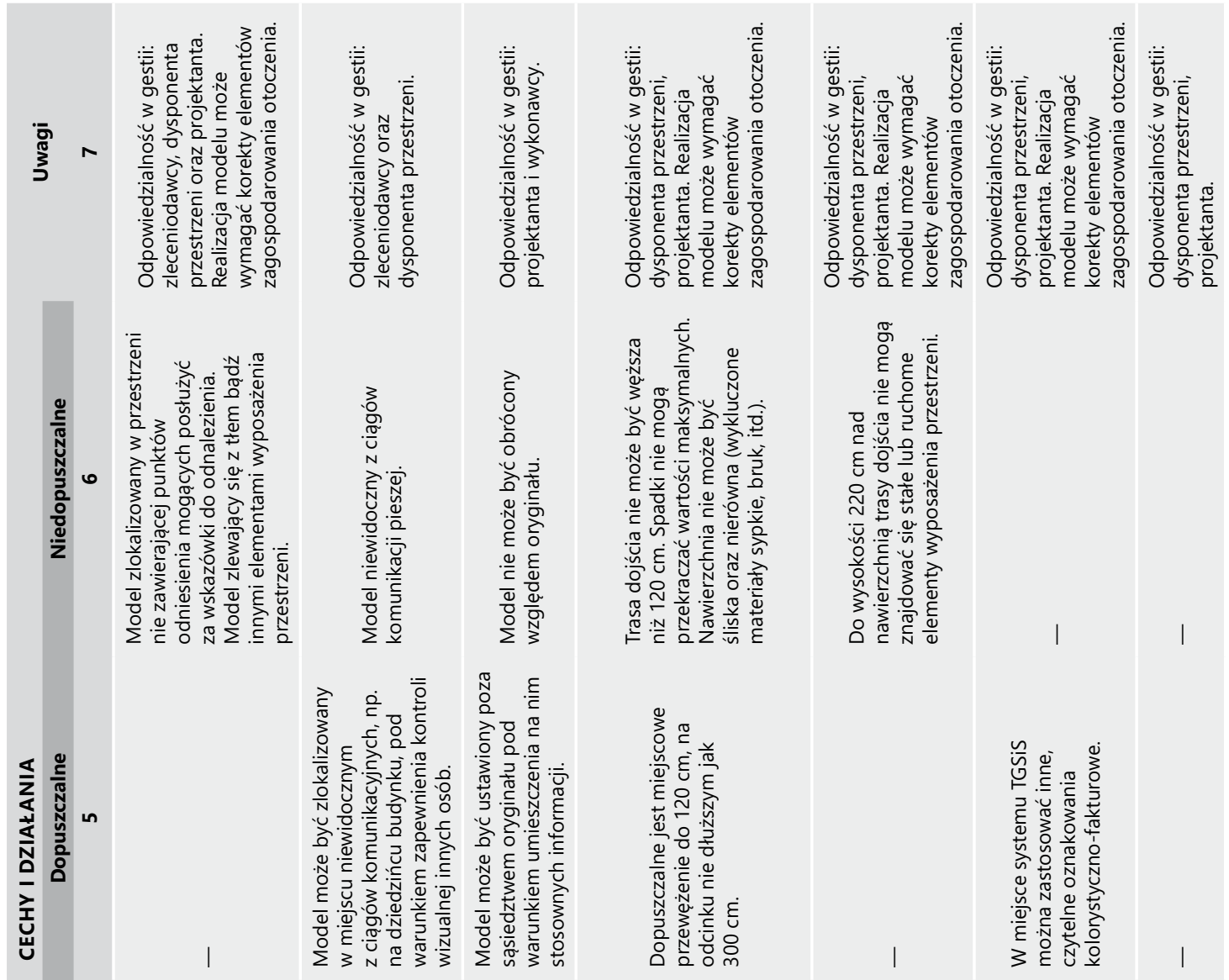

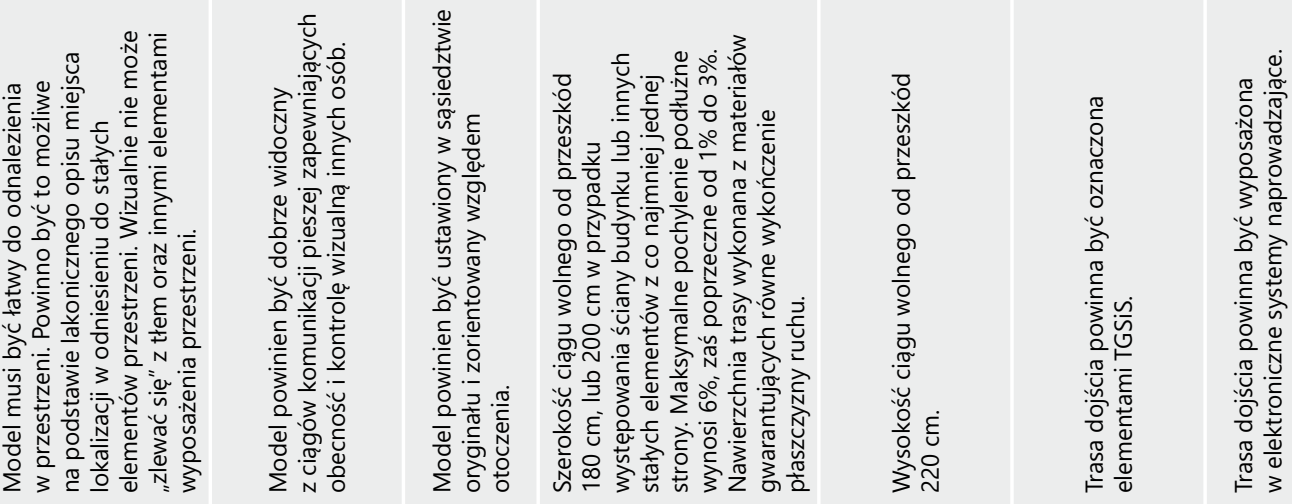
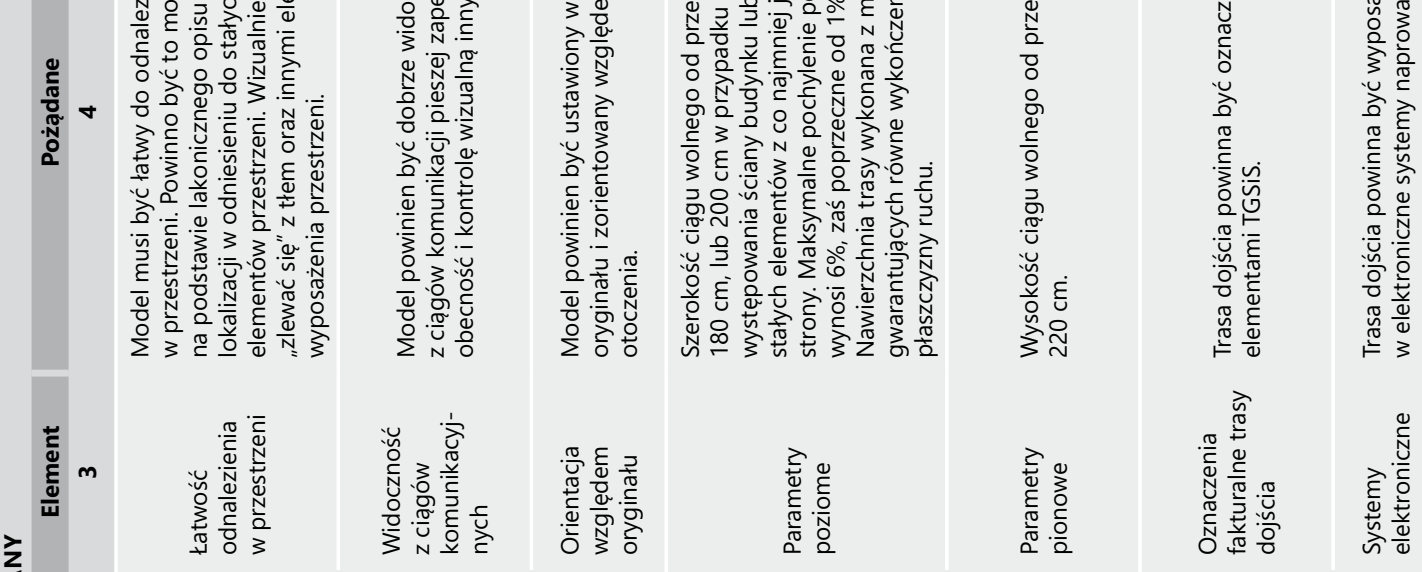

əวรโอ!พ

eipșfop estu

әэёевремолdeu

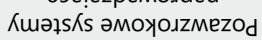




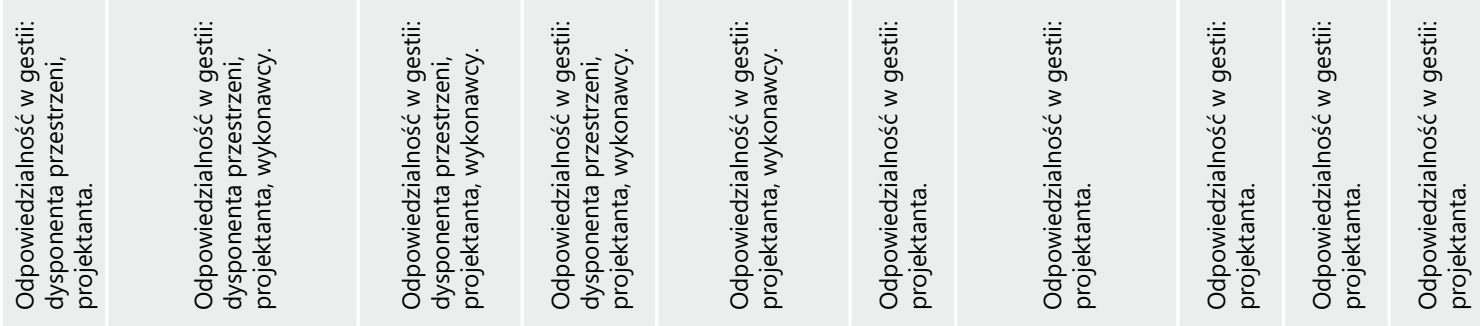

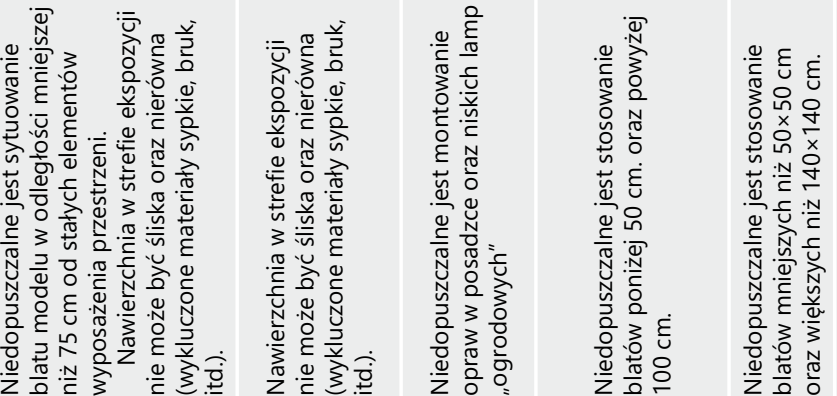
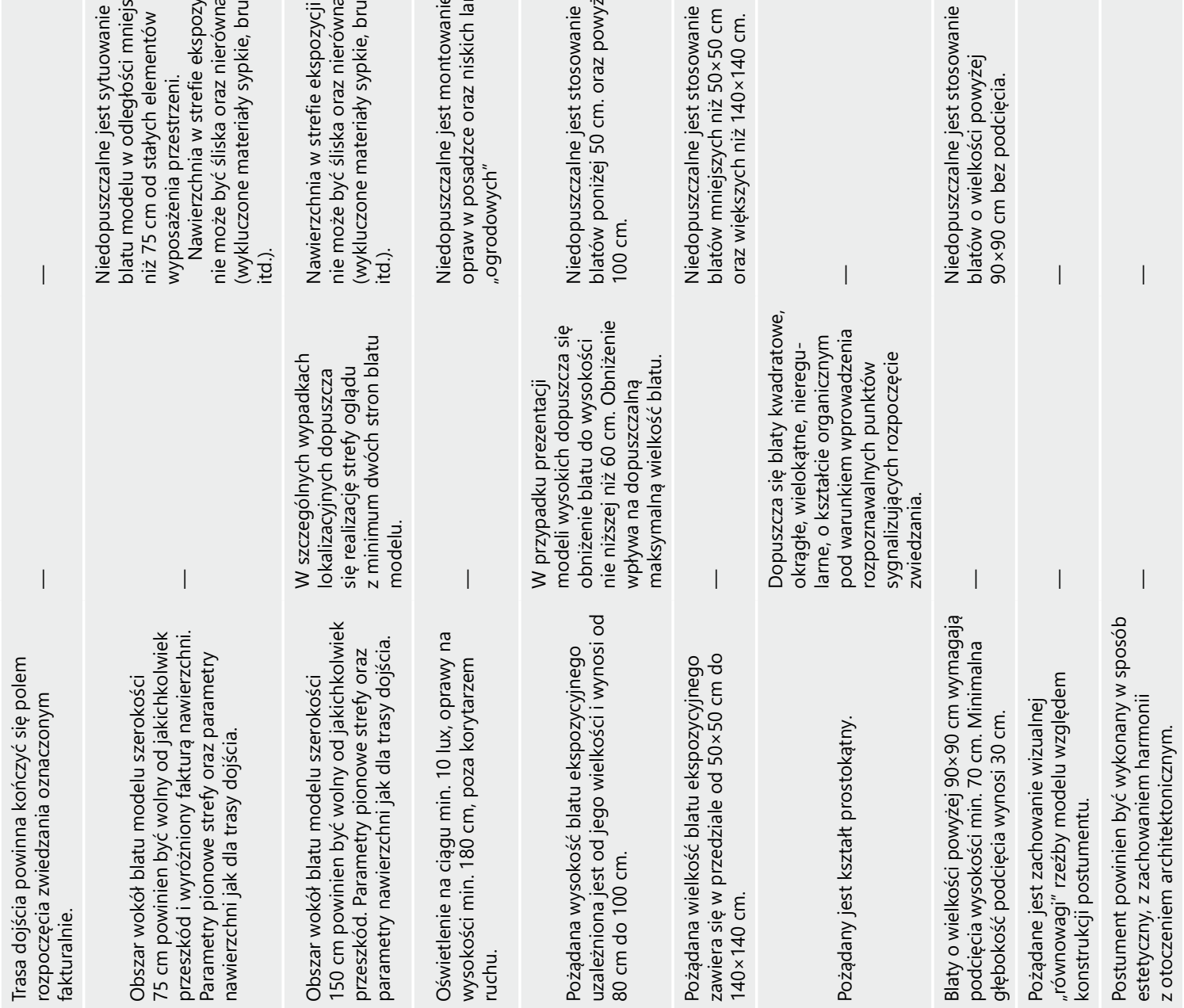

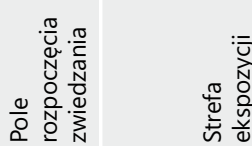
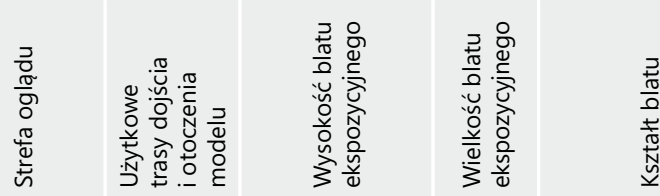

nјәрош ә!цәzวоғо 

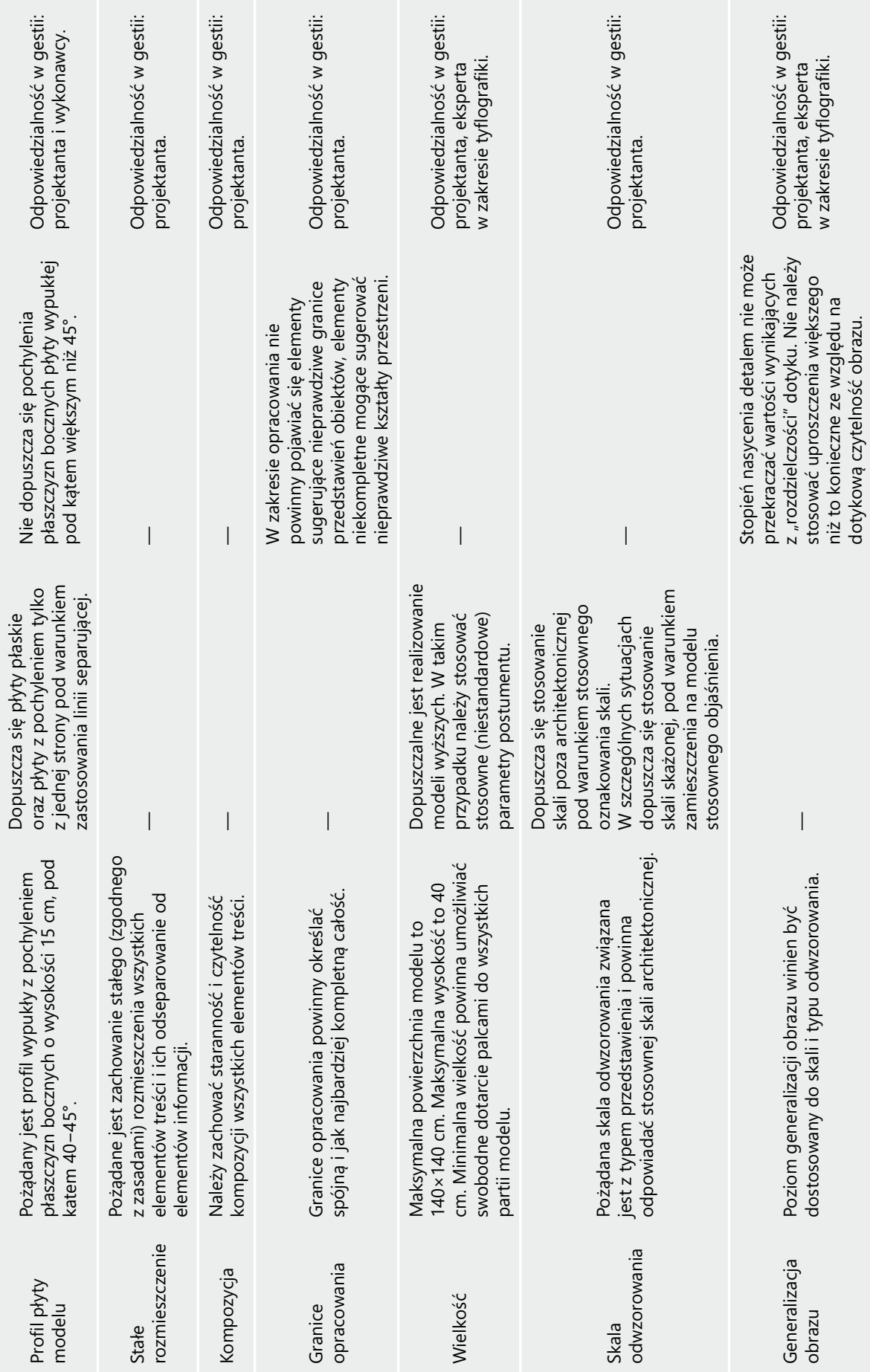

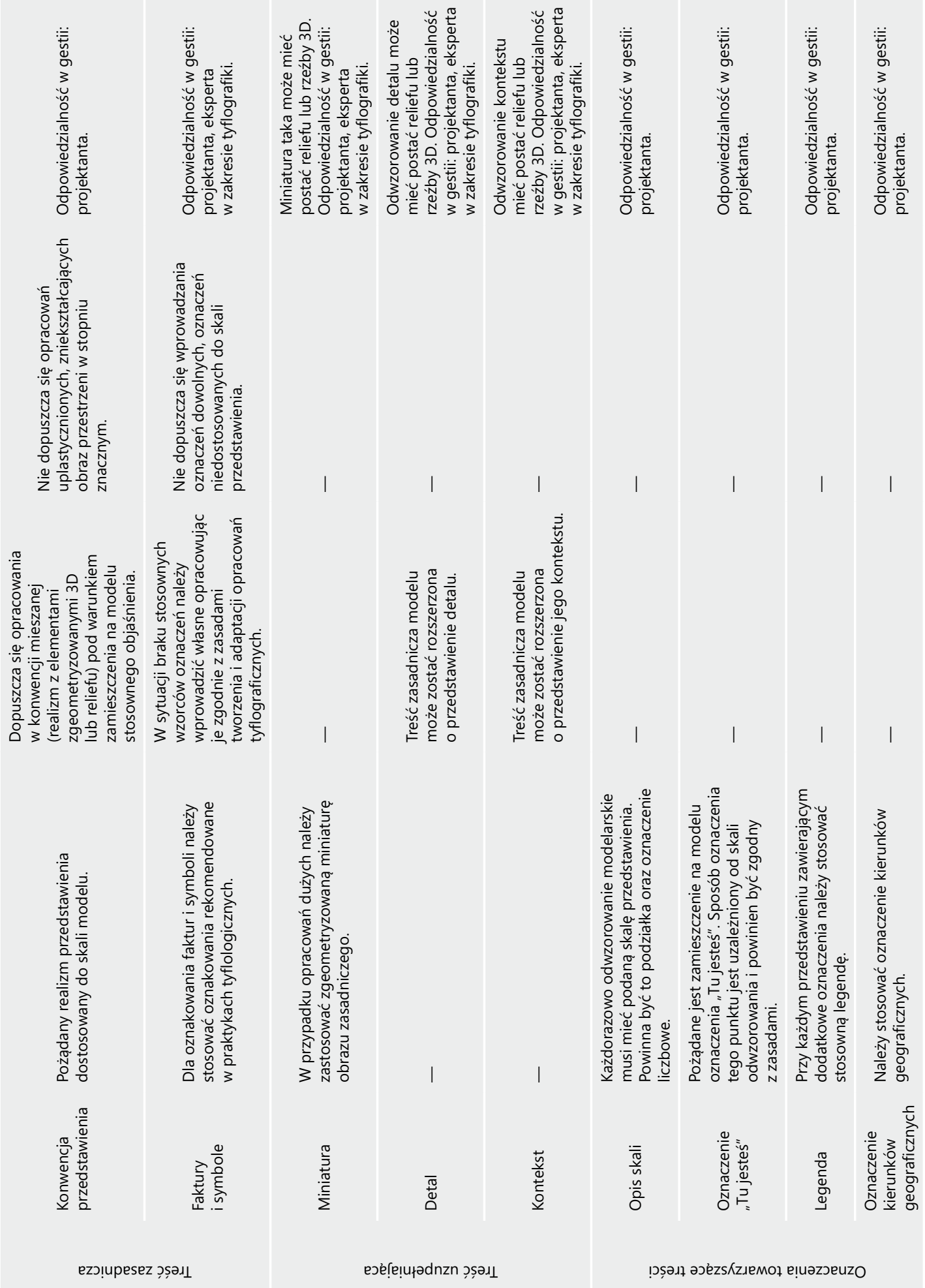

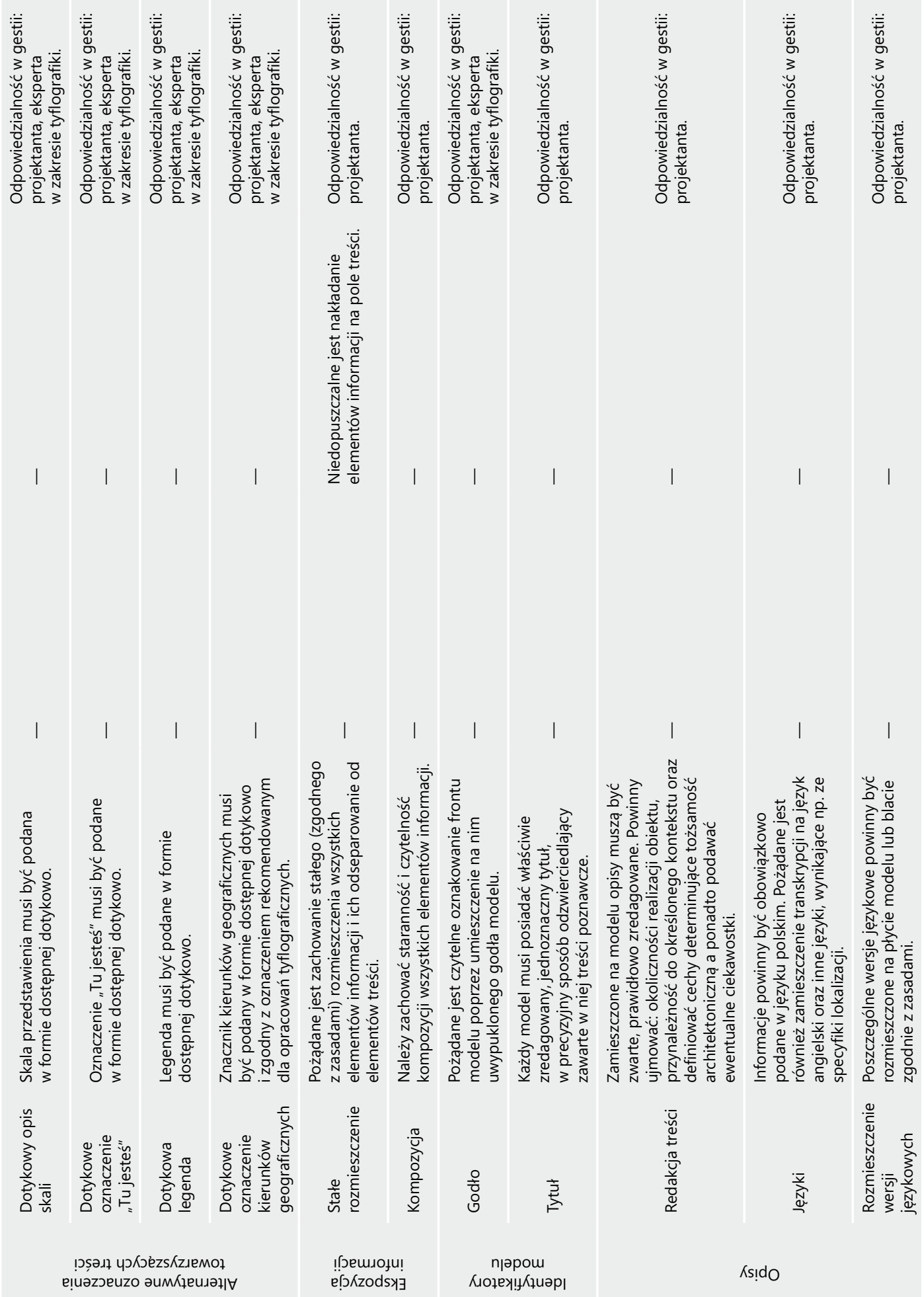

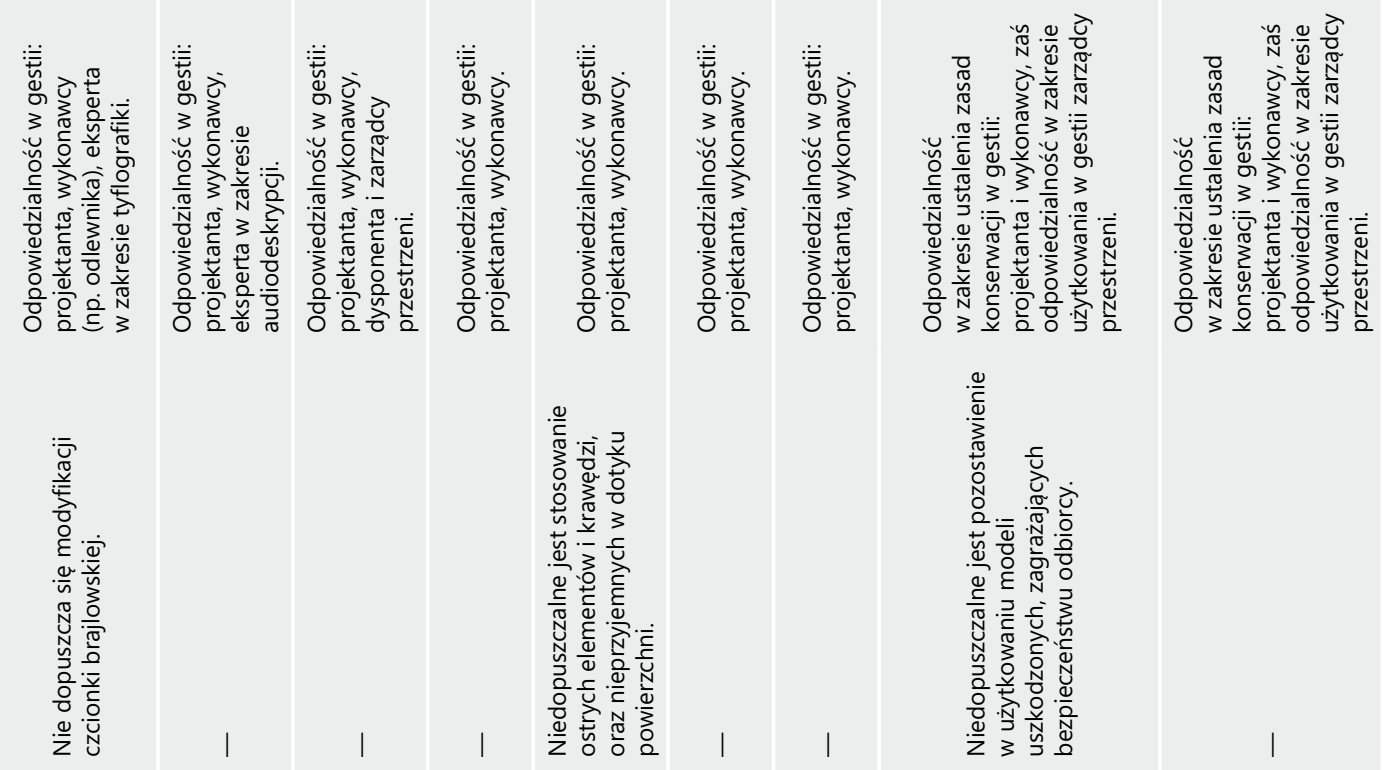

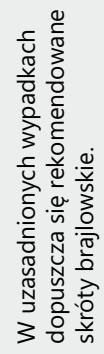

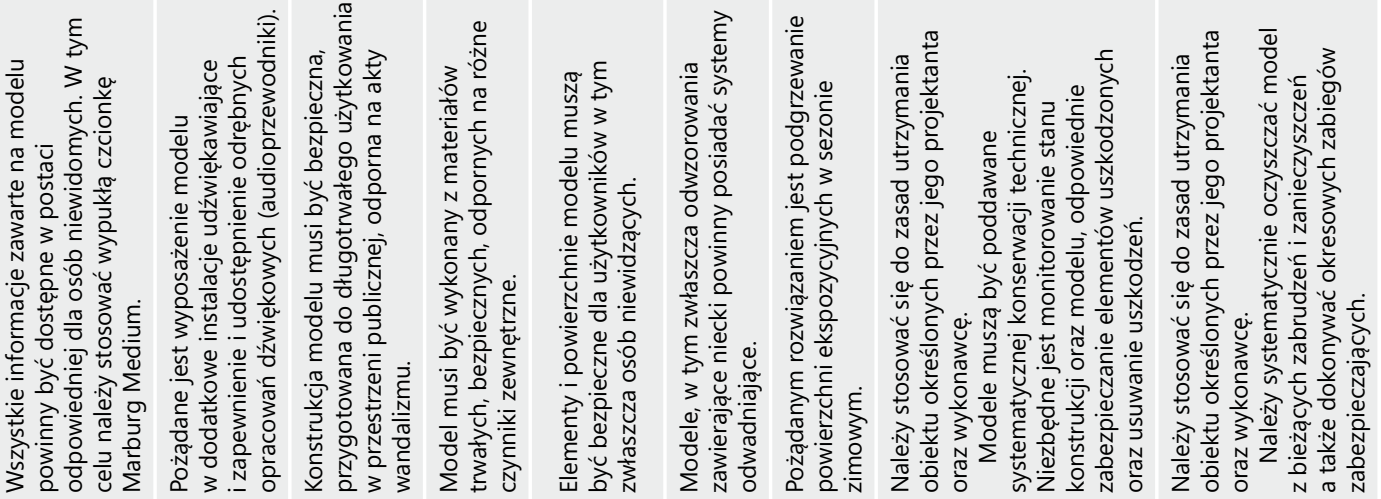

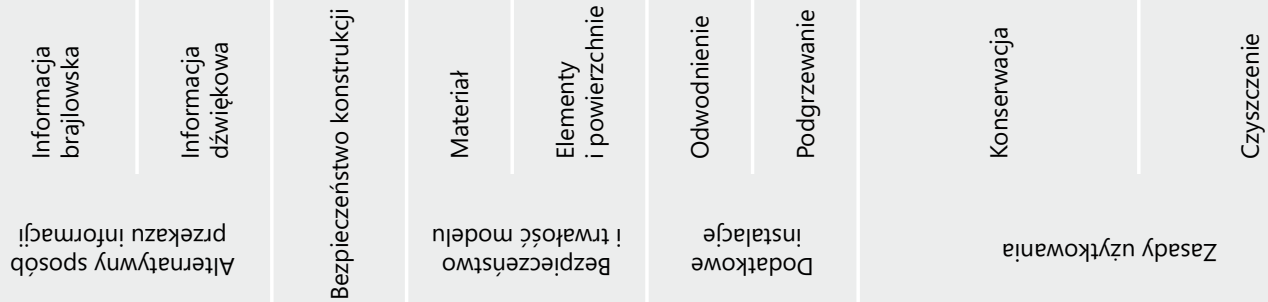




\section{Literatura}

[1] Czarnecki B., Siemiński W., Kształtowanie bezpiecznej przestrzeni publicznej, Centrum Doradztwa i Informacji Difin, sp. z o.o., Warszawa 2004.

[2] Grabowska-Pałecka H., Niepetnosprawni w obszarach i obiektach zabytkowych. Problemy dostępności, Politechnika Krakowska, Kraków 2004.

[3] Jakubowski M., Gdzie wzrok nie sięga, czyli „nie od razu Kraków zbudowano..., Tyfloświat, Nr 1(10) 2011, s. $25-28$.

[4] Kłopotowska A., Doświadczanie przestrzeni w rehabilitacji osób z dysfunkcją wzroku. Sztuka a tyflorehabilitacja, Oficyna Wydawnicza PB, Białystok 2016,

[5] Kłopotowska A., Dotykowe modele architektoniczne w przestrzeni miejskiej. Część I - Diagnoza problemów obiektów zrealizowanych w Polsce, w: Materiaty z III ogólnopolskiej konferencji naukowo-szkoleniowej pt.: "Medycyna personalizowana. Genom-człowiek-świat-zagrożenia", Lublin, Polihymnia 2016, s. 167.

[6] Kłopotowska A., Kłopotowski M., Badania nad standaryzacją dotykowych makiet i modeli architektonicznych instalowanych w przestrzeni zewnętrznej, w: Materiały z konferencji pt.: "Nowocześni niewidomi i słabowidzący w dostosowanym dla nich świecie", Serock 2016, s. 32-34.

[7] Kłopotowska A., Kłopotowski M., Dotykowe modele architektoniczne w przestrzeniach polskich miast. Część I. Standardy, rękopis autorów.

[8] Kłopotowska A., Kłopotowski M., Dotykowe modele architektoniczne w przestrzeniach polskich miast. Część I. Realizacje, rękopis autorów.

[9] Kłopotowski M., Dotykowe modele architektoniczne w przestrzeni miejskiej. Część II - wytyczne projektowe, w: Materiały z III Ogólnopolskiej konferencji naukowo-szkoleniowej pt.: "Medycyna personalizowana. Genom-człowiek-świat-zagrożenia", Lublin, Polihymnia 2016, s. 168.

[10] Kuryłowicz E., Projektowanie uniwersalne. Udostępnianie otoczenia osobom niepetnosprawnym, Centrum Badawczo-Rozwojowe Rehabilitacji Osób Niepełnosprawnych, Warszawa 1996.

[11] Więckowska E. (red.), Instrukcja tworzenia i adaptowania ilustracji i materiałów tyflograficznych dla uczniów niewidomych, http://pzn.org.pl/wp-content/uploads/2016/07/instrukcja_tworzenia_i_adaptowania_ilustracji_i_materialow_tyflograficznych_dla_niewidomych.pdf, dostęp/access 2017-09-12.

[12] Więckowska E. (red.), Standardy tworzenia oraz adaptowania map i atlasów dla niewidomych uczniów, file:///C:/Users/ user/Downloads/Standardy_tworzenia_oraz_adaptowania_map_i_atlasow_dla_niewidomych_uczniow\%20(5).pdf, dostęp/ access 2017-09-12.

[13] Wysocki M., Projektowanie otoczenia dla osób niewidomych. Pozawzrokowa percepcja przestrzeni, Wydawnictwa Politechniki Gdańskiej, Gdańsk 2010.

[14] Wysocki M., Standardy dostępności dla Miasta Gdyni, według kopii cyfrowej, dostęp online w: https://arch4all5.files. wordpress.com/2013/10/standardy-dostc499pnoc59bci-dla-m-gdyni-2013-opti.pdf, stan z dn. 04.04.2016.

[15] Wyżykowski A. P. (red.), Przestrzeń bezpieczna, Wydawnictwa Politechniki Krakowskiej, Kraków 2004. 